\title{
Pengaruhi Mahasiswa Akuntansi Memilih Enterpreneuship Dengan Menggunakan TPB Di Universitas Medan
}

\section{The Influence Accounting Students Choosing Enterpreneuship With Using TPB in University in Medan}

\author{
Vina Arnita* \& Handriyani Dwilita \\ Program Studi Akuntansi, Fakultas Sosial Sains, Universitas Pembangunan Panca Budi \\ Indonesia
}

Diterima: 17 September 2020; Direview: 26 September 2020; Disetujui: 03 November 2020 *Coresponding Email: vinaarnita@dosen.pancabudi.ac.id

\section{Abstrak}

Penelitian ini menguji apakah faktor-faktor yang mempengaruhi mahasiswa akuntansi menjadi wirausaha di Universitas Pembangunan Panca Budi dengan menggunakan theory of planned behaviour. Adapun variabel yang mempengaruhi yaitu pengaruh sikap mandiri, pengaruh motivasi, berminat berwirausaha mahasiswa di Universitas Pembangunan Panca Budi Medan. Kemudian data yang diperoleh dianalisis dengan menggunakan analisis regresi berganda, uji normalitas data, uji multikolinearitas dan uji heterokedastisitas. Metode yang digunakan uji analisis faktor dengan melihat pengaruhi setiap variabel. Dalam penelitian ini menggunakan theory planned behaviouruntuk melihat mahasiswa akuntansi memilih menjadi wirausaha. Adapun hasil dari penelitian ini adalah adanya pengaruh yang tinggi terhadap ketiga variabel dengan menggunakan theory Planned Behaviour terhadap mahasiswa akuntansi menjadi wirausaha. Pengaruh terhadap ketiga variabel cenderung mempengaruhi mahasiswa memilih menjadi wirausaha. Fenomena ini terjadi dikarenakan banyak cafe ataupun toko minuman yang beredar dikota medan. Ini terjadi dikarenakan peluang menjadi wirausaha sangat besar dan yang menjadi pemilik dari cafe ataupun toko adalah mahasiswa yang sedang kuliah ataupun sudah selesai kuliah. Dengan adanya cafe yang bermunculan sehingga menciptakan lapangan pekerjaan bagi mahasiswa yang sedang kuliah ataupun yang sedang magang.

Kata Kunci: Sikap Mandiri, Motivasi, Berminat Berwirausaha

\begin{abstract}
This study examines whether the factors that influence accounting students become entrepreneurs at Panca Budi Development University using the theory of planned behavior. The variables that influence are the influence of independent attitude, the influence of motivation, student's interest in entrepreneurship at the University of Development Panca Budi Medan. Then the data obtained were analyzed using multiple regression analysis, data normality test, multicollinearity test and heterokedasticity test. The method used is a factor analysis test by looking at the effect of each variable.In this study using the theory of planned behavior to see accounting students choose to become entrepreneurs. The results of this study are the existence of a high influence on the three variables using the Planned Behavior theory of accounting students to become entrepreneurs. The influence of the three variables tends to influence students choosing to become entrepreneurs. This phenomenon occurs because many cafes or beverage shops are circulating in the city of Medan. This happens because the opportunity to become an entrepreneur is very large and the owner of the cafe or shop is a student who is in college or has finished college. With a cafe that has sprung up so as to create jobs for students who are in college or who are on an internship Keywords: Independent Attitude, Motivation, Entrepreneurial Interest
\end{abstract}

How to Cite: Arnita, V. \& Dwilita, H. (2020), Pengaruhi Mahasiswa Akuntansi Memilih Enterpreneuship Dengan Menggunakan TPB Di Universitas Medan, Journal of Education, Humaniora and Social Sciences (JEHSS). 1 (3): 560565. 


\section{PENDAHULUAN}

Dalam perkembangan perekonomian suatu negara, wirausahawan telah menjadi perhatian yang penting (Carree \& Thurik, 2010) dalam menekan kegiatan ekonomi suatu negara dalam meningkatkan pertumbuhan ekonomi. Inovasi tersebut meliputi memperkenalkan barangbarang baru, mempertinggi efisiensi dalam memproduksi suatu barang, memperluas pasar suatu barang ke pasaran yang baru, mengembangkan sumber bahan mentah yang baru, dan mengadakan perubahan dalam organisasi.

Peranan wirausahawan sangat dibutuhkan oleh suatu negara karena ikut pula menentukan keberhasilan pembangunan nasional. Adapun peranan wirausahawan didalam suatu negara adalah meningkatkan kegiatan ekonomi suatu negara, memajukan ekonomi bangsa dan negara, meningkatkan taraf hidup masyarakat, ikut mengurangi atau mengatasi pengangguran, ikut mengatasi ketegangan sosial, meningkatkan perdagangan domestik dalam negeri maupun perdagangan internasional, ikut meningkatkan devisa negara, meningkatkan pengelolaan sumber daya alam, sumber daya manusia, dan sumber daya modal (Cahyani, 2012).

Dalam hal ini, tidak dipungkiri bahwa kehadiran dan peranan wirausaha akan memberikan pengaruh terhadap kemajuan perekonomian dan perbaikan pada keadaan ekonomi di Indonesia, dapat menciptakan lapangan kerja, meningkatkan kualitas hidup masyarakat, meningkatkan pemerataan pendapatan, memanfaatkan dan memobilisasi sumberdaya untuk meningkatkan produktivitas nasional, serta meningkatkan kesejahteraan pemerintahan. Dengan demikian, meningkatnya perkembangan kewirausahaan dapat meningkatkan perekonomian di Indonesia.

Dalam hubungannya dengan kewirausahaan, hal ini tidak dapat lepas dari individu yang terlibat di dalamnya. Individu yang bergelut dalam kewirausahaan tersebut biasa disebut dengan wirausaha. Menurut kamus besar bahasa Indonesia, wirausaha adalah orang yang pandai atau berbakat mengenali produk baru, menentukan cara produksi baru, menyusun operasi untuk mengadakan produk baru, mengatur permodalan operasinya serta memasarkannya.

Soemanto (2002) mengatakan bahwa satu-satunya perjuangan atau cara untuk mewujudkan manusia yang mempunyai moral, sikap, dan keterampilan wirausaha adalah dengan pendidikan. Pendidikan membuat wawasan individu menjadi lebih percaya diri, bisa memilih, dan mengambil keputusan yang tepat, meningkatkan kreativitas dan inovasi, membina moral, karakter, intelektual, serta peningkatan. Dalam rangka mendorong tumbuhnya jiwa kewirausahaan bagi para mahasiswa dan menciptakan lulusan mahasiswa Fakultas sosial dan sains Universitas Pembangunan Panca Budi yang mampu menjadi pencipta lapangan kerja, maka perlu diadakan pembinaan bagi mahasiswa agar mampu melaksanakan wirausaha.

Mahasiswa Fakultas sosial dan sains yang berkonsentrasi kewirausahaan diarahkan untuk mengikuti berbagai program dalam rangka menumbuhkan aktivitas wirausaha dalam lingkungan mahasiswa, seperti kuliah kewirausahaan, magang kewirausahaan, simulasi bisnis, bisnis plan yang akan menjadi sumber inspirasi bagi mahasiswa kelak lulus nanti.

Dengan demikian, meningkatnya perkembangan kewirausahaan dapat meningkatkan perekonomian di Indonesia. Dalam hubungannya dengan kewirausahaan, hal ini tidak dapat lepas dari individu yang terlibat di dalamnya. Individu yang bergelut dalam kewirausahaan tersebut biasa disebut dengan wirausaha. Menurut kamus besar bahasa indonesia, wirausaha adalah orang yang pandai atau berbakat mengenali produk baru, menentukan cara produksi baru, menyusun operasi untuk mengadakan produk baru, mengatur permodalan operasinya serta memasarkannya. Soemanto (2002) mengatakan bahwa satu-satunya perjuangan atau cara untuk mewujudkan manusia yangmempunyai moral, sikap, dan keterampilan wirausaha adalah dengan pendidikan. Pendidikan membuat wawasan individu menjadi lebih percaya diri, bisa memilih, dan mengambil keputusan yang tepat, meningkatkan kreativitas dan inovasi, membina moral, karakter, intelektual, serta peningkatan.

Dalam rangka mendorong tumbuhnya jiwa kewirausahaan bagi para mahasiswa dan menciptakan lulusan mahasiswa Fakultas Sosial dan Sains Universitas Pembangunan Panca Budi yang mampu menjadi pencipta lapangan kerja, maka perlu diadakan pembinaan bagi mahasiswa agar mampu melaksanakan wirausaha. Mahasiswa Fakultas Sosial dan Sains Universitas 
Pembangunan Panca Budi yang berkonsentrasi kewirausahaan diarahkan untuk mengikuti berbagai program dalam rangka menumbuhkan aktivitas wirausaha dalam lingkungan mahasiswa, seperti kuliah kewirausahaan, magang kewirausahaan, simulasi bisnis, bisnis plan yang akan menjadi sumber inspirasi bagi mahasiswa kelak lulus nanti

Menurut Astuti (2015) bahwa penelitian ini memiliki objek digunakan anak sekolah menengah atas dengan penggunaan variable motivasi dan minat berwirausaha.Hasil dari penelitian ini anak sekolah menengah atas mampu menunjukkan minat berwirausaha dengan membuktikan sebagian koresponden sudah mencoba berwirausaha baik secara online maupun ofline.

\section{METODE PENELITIAN}

Jenis penelitian yang dilakukan adalah penelitian deskriptif asosiatif. Menurut Ayuningtiyas (2015) penelitian asosiatif kausal adalah penelitian yang bertujuan untuk menganalisis hubungan antara variabel bebas terhadap variabel terikat serta variabel mediasi guna mengetahui keakuratan dalam memprediksi gejala (fenomena) yang ada. Ruang lingkup penelitian ini dibatasi hanya dalam mahasiswa semester 5 dan 7 yang memilih jurusan akuntansi.Adapun teknik pengumpulan data dalam penelitian ini dengan menggunakan kuesioner, seperti yang dikemukakan oleh Sugiyono (2007), Kuesioner merupakan teknik pengumpulan data yang dilakukan dengan cara memberi seperangkat pertanyaan atau pertanyaan tertulis kepada responden untuk dijawabnya. Kualitas instrument penelitian dapat dievaluasi melalui uji realibilitas dan validitas.Pengujian ini dilakukan untuk mengetahui masing-masing konsistensi dan akurasi data yang dikumpulkan dari penggunaan instrumen (Sugiyono, 2007). Jenis data dalam penelitian ini adalah jenis data primer yaitu data yang harus dilakukan pengolahan kembali untuk mendapatkan data yang sebenarnya. Data primer dapat berupa data wawancara atau kuisioner.

Sumber data dalam penelitian ini adalah sumber data primer yaitu sumber data yang secara langsung memberikan data kepada pengumpul data (Sugiyono, 2007). Sumber data dalam penelitian ini berasal dari mahasiswa Universitas Pembangunan Pancabudi Medan.Populasi yang akan digunakan dalam penelitian ini adalah Mahasiswa yang mengambil jurusan akuntansi dan yang dipilih mahasiswa semester 5 dan 7 yang berada di Universitas Pembangunan Pancabudi Medan Sumatera Utara berjumlah 500 mahasiswa. Teknik penarikan sampel menggunakan teknik exidental sampling yaitu sampel yang dijumpai secara langsung yang bersedia mengisi data penelitian berupa kuisioner.Dalam penelitian ini metode analisis data yang digunakan adalah regresi linier berganda (multiple linier regression method) yang dimodifikasi menggunakan analisis jalur denganbantuan Software SPSS (Statistical Package Social Science).Model analisis dengan menggunakan uji asumsi klasik yaitu uji normalitas, uji autokorelasi dan uji multikorelasi

\section{HASIL DAN PEMBAHASAN}

Pada bab ini menceritakan tentang hasil penelitian masing-masing variabel dan setiap variabel menjelaskan adanya hubungan antara setiap variabel. Adapun hasil dari penelitian ini adalah sebagai berikut: Penelitian ini meneliti mengenai faktor-faktor yang mempengaruhi mahasiswa akuntansi untuk berwirausaha. Faktor tersebut dibagi dalam 2 faktor antara lain: sikap mandiri, motivasi dan minat berwirausaha. Populasi dalam penelitian ini adalah seluruh mahasiswa S1 Jurusan Akuntansi di Universitas Pembangunan Panca Budi Medan. Sampel dalam penelitian ini adalah mahasiswa Jurusan Akuntansi S1 di Universitas Pembangunan Panca Budi Medan. Teknik 
pengambilan sampel yang digunakan adalah Sampling Insidental (accidental sampling). Accidental sampling adalah teknik penentuan sampel berdasarkan kebetulan, yaitu siapa saja yang secara kebetulan/insidental bertemu dengan peneliti dapat digunakan sebagai sampel, bila dipandang orang yang kebetulan cocok sebagai sumber data (Sugiyono, 2007. Teknik pengumpulan data primer pada penelitian ini adalah dengan cara membagikan kuesioner kepada Mahasiswa Jurusan Akuntansi di Universitas Pembangunan Panca Budi Medan. Keputusan mahasiswa akuntansi memilih berwirausaha sebagai bentuk alternatif untuk memperaktikan perkuliahan akuntansi dibidang usaha.

\section{Faktor Analisis untuk Sikap Mandiri}

Faktor analisis mengidentifikasikan lebih besar 2.139 dan total indikasi variancenya 72,7\%. Kaiser-Meyer-Olkin (KMO) was 0.5 mengidentifikasikan korelasi. Hasil dari faktor analisis dari pengaruh sikap mandiri ditunjukan pada tabel 4.1 adalah.

Table 1 Hasil dari pengaruh sikap mandiri dari faktor analisis

\begin{tabular}{clc}
\hline No & \multicolumn{1}{c}{ Keterangan } & Hasil \\
\hline $\mathbf{1}$ & Saya pandai mengambil inisiatif dalam sebuah peluang usaha & 0.853 \\
\hline $\mathbf{2}$ & $\begin{array}{l}\text { Saya mampu mengatasi rintangan atau permasalahan di dalam lingkungan usaha } \\
\text { tanpa bantuan orang lain. }\end{array}$ & 0.853 \\
\hline 3 & $\begin{array}{l}\text { Saya mampu mendorong diri sendiri agar mempunyai kepribadian atau tingkah laku } \\
\text { yang lebih baik ketika mengalami kegagalan dalam mencari peluang usaha. }\end{array}$ & 0.756 \\
\hline 4 & $\begin{array}{l}\text { Saya mampu mengerjakan dan menyelesaikan sendiri permasalahan yang ada dalam } \\
\text { usaha }\end{array}$ & 0.675 \\
\hline
\end{tabular}

Sumber: Data Penelitian, 2020

\section{Faktor Analisis untuk Pengaruh Motivasi}

Faktor analisis mengidentifikasikan lebih besar 2.256 dan total indikasi variancenya $78 \%$. Kaiser-Meyer-Olkin (KMO) was 0.55 mengidentifikasikan korelasi. Hasil dari faktor analisis dari pengaruh motivasi ditunjukan pada tabel 4.2 adalah.

Table 2 Hasil dari Faktor analisis dari pengaruh motivasi

\begin{tabular}{lllll}
\hline No & Keterangan & Hasil \\
\hline 1 & Saya berminat menjadi wirausahawan karena memiliki keinginan untuk menjadi kaya. & 0.531 \\
\hline 2 & $\begin{array}{l}\text { Saya berminat menjadi wirausahawan karena mempunyai kepandaian untuk } \\
\text { mengenali peluang usaha yang ada. }\end{array}$ & 0.581 \\
\hline 3 & $\begin{array}{l}\text { Saya berminat menjadi wirausahawan karena mampu menciptakan nilai tambah } \\
\text { dalam suatu produk. }\end{array}$ & 0.637 \\
\hline
\end{tabular}

Sumber :Data Penelitian,2020

\section{Faktor Analisis untuk Minat Berwirausaha}

Faktor analisis mengidentifikasikan lebih besar 2.089 dan total indikasi variancenya 71.1\%. Kaiser-Meyer-Olkin (KMO) was 0.15 mengidentifikasikan tidak korelasi. Hasil dari faktor analisis dari Minat Berwirausaha ditunjukan pada tabel 4.3 adalah.

Table 3 Hasil dari Faktor Analisis dari Minat Berwirausaha

\begin{tabular}{|c|c|c|}
\hline No & Keterangan & Hasil \\
\hline 1 & Saya mempunyai keyakinan diri bahwa mampu untuk berwirausaha. & 0.723 \\
\hline 2 & Saya mempunyai sikap jujur dan tanggung jawab dalam berwirausaha & 0.534 \\
\hline 3 & Saya mempunyai ketahanan fisik, mental, ketekunan dalam memulai usaha yang baru & 0.845 \\
\hline 4 & Saya bekerja dan berusaha untuk memulai usaha yang baru & 0.875 \\
\hline 5 & Saya mempunyai pemikiran yang kreatif untuk menemukan produk baru. & 0.765 \\
\hline 6 & Saya mempunyai pemikiran yang kontruktif untuk menemukan produk baru. & 0.556 \\
\hline 7 & Saya berorientasi ke masa depan dalam berwirausaha. & 0.543 \\
\hline 8 & Saya berani mengambil resiko dalam berwirausaha & 0.634 \\
\hline
\end{tabular}




\section{Sumber :Data Penelitian, 2020}

Sikap adalah sebagai suatu kesiapan mental atau emosional dalam beberapa jenis tindakan pada suatu yang tepat (Djaali, 2008). Sedangkan menurut Slamet (2003) sikap merupakan sesuatu yang dipelajari dan bagaimana individu bereaksi terhadap situasi serta menentukan apa yang dicari individu dalam kehidupan. Dimensi kepribadian seseorang selalu dipengaruhi atau dikendalikan faktor internal dan faktor eksternal. Bagi sebagian orang, kekuatannya selalu tergantung pada dirinya sendiri tetapi bagi orang lain kekuatannya tidak tergantung pada dirinya sendiri melainkan faktor eksternal seperti orang lain, nasib, keberuntungan atau kebetulan. Dikatakan sikap mandiri apabila orang tersebut mampu mendewasakan dirinya sendiri, dan apabila berhasil mendewasakan dirinya sendiri akan mampu membentuk pendapat atau pandangannya sendiri tentang masalah atau peristiwa yang terjadi dalam lingkungannya.

Dengan memiliki kemampuan dalam menghadapi masalah dan peristiwa tersebut maka individu akan mampu pula membentuk pandangan yang paling baik bagi orang lain. Orang yang selalu mengandalkan kekuatan yang ada pada dirinya sendiri disebut juga mempunyai keinginan untuk menguasai dan mengendalikan tindakan-tindakan sendiri dengan tidak mengharapkan bantuan atau pengaruh orang lain. Sikap mandiri adalah kemampuan seseorang berdiri sendiri dalam segala aspek kehidupannya.

Dengan demikian individu yang berdiri di atas kaki sendiri akan mengambil inisiatif, mengatasi sendiri kesulitan-kesulitannya dan ingin melakukan hal-hal oleh dirinya sendiri. Tanda-tanda dari sikap sendiri adalah pengambilan inisiatif, mencoba mengatasi rintanganrintangan dalam lingkungannya, mencoba mengarahkan tingkah laku ke arah yang sempurna, memperoleh kepuasan dari bekerja, dan mencoba mengerjakan sendiri tugas-tugas rutinnya.

Motivasi merupakan faktor yang sangat berpengaruh pada diri seseorang untuk menentukan apa yang menjadi keinginan dan usahanya untuk mewujudkan keinginannya tersebut. Menurut Bakti (2015), Motivasi adalah dorongan dasar yang menggerakkan seseorang bertingkah laku. Cahyaning (2014) Motivasi dapat dipahami sebagai keadaan dalam diri individu yang menyebabkan mereka berperilaku dengan cara yang menjamin tercapainya suatu tujuan. Limbong (2010) juga berpendapat bahwa motivasi adalah suatu dorongan dari dalam diri seseorang yang mendorong orang tersebut untuk melakukan sesuatu, termasuk menjadi young entrepreneur. Paulina (2011) mengemukakan bahwa motivasi adalah dorongan dan arahan perilaku.

\section{SIMPULAN}

Sikap mandiri berpengaruh signifikan terhadap minat berwirausaha.Dengan kata lain sikap mandiri yang ada pada diri mahasiswa memiliki sikap tanggung jawab apa yang telah mereka pilih. Di universitas Pembangunan Panca Budi mahasiswa didik untuk berwirausaha dilingkungan universitas sehingga menumbuhkan rasa percaya yang tinggi terhadap mahasiswa dalam melakukan usaha yang mereka tawarkan baik kepada dosen ataupun staff pegawai.Motivasi juga berpengaruh signifikan terhadap minat berwirausaha karena memiliki kemauan yang tinggi dan memiliki keinginan tinggi dan muncul rasa keinginan tahuan terhadap beriwirausaha.

\section{UCAPAN TERIMAKASIH}

Ucapan terima kasih disampaikan kepada pihak universitas yang telah memberikan pembiayaan dalam penelitian ini

\section{DAFTAR PUSTAKA}

Carree, M., \& Thurik, A. R. (2010). The Impact of Entrepreneurship on Economic Growth. In Handbook of Entrepreneurship Research (pp. 557-594). http://doi.org/10.1007/978-1-4419-1191-9_20

Ayuningtiyas, A. H. dan Ekawati, S. (2015). Faktor - faktor yang Mempengaruhi Minta Berwirausaha pada Mahasiswa Fakultas Ekonomi Universitas Hendrawan, Sirine 312 Tarumanagara. Jakarta: Jurnal Ekonomi, Volume XX, No.01. 
Astuti, f. K. (2015). Upaya meningkatkan minat kewirausahaan melalui diskusi kelompok pada siswa kelas xi smk negeri i sanden. Jurnal riset mahasiswa bimbingan dan konseling, 4(3).

Bakti, A. (2015). Minat Berwirausaha. Diakses dari http://ketertarikanberwirausaha.blogsp ot.co.id/2015/03/minatberwirausaham engindikasikan.htmlyang diakses pada tanggal 01 Juni 2016

Cardinawati. (2010). Minat Berwirausaha Mahasiswa Pendidikan Ekonomi Fakultas Keguruan dan Ilmu Pendidikan UKSW.

Cahyaning, P. (2014). Pengaruh Sikap Mandiri dan Pengaruh Teman Sebaya terhadap Minat Berwirausaha pada Mahasiswa Program Studi Pendidikan Akuntansi Angkatan 2011 Muhamadiah Surakarta. Diakses dari https://putrielvinacahyaning.wordpress .com/ pada tanggal 28 Maret 2016.

Djaali, H. (2008). Psikologi pendidikan. Jakarta: Bumi Aksara, 138.

Ghozali, I. (2016). Aplikasi Analisis Multivariate dengan Program SPSS. Semarang: Badan Penerbit Universitas Diponegoro. ISBN: 979.704.015.1.

Limbong, (2010). Pengaruh antara Sikap Mandiri, Pengetahuan Kewirausahaan Dan Motivasi Berwirausaha terhadap Minat Berwirausaha Siswa-Siswi SMK di Kota Medan. Skripsi yang Tidak Dipublikasikan. Medan: Jurusan Manajemen, Universitas Sumatera Utara.

Muhidin. (2011). Panduan Praktis Memahami Penelitian. Bandung: Pustaka Setia.

Mulyaningsih. (2012). Faktor-Faktor Yang Mempengaruhi Minat Wirausaha Pengelolaan Pangan Organik. Malang: Journal Wacana. AJIE - Vol. 02, No. 03, September 2017313

Mustofa, A. M. (2014). Pengaruh Pengetahuan Kewirausahaan, Self Efficacy, DanKarakter Wirausaha Terhadap Minat Berwirausaha Pada Siswa Kelas XI SMK Negeri 1 Depok Kabupaten Sleman. Yogyakarta: eprints UNY.

Paulina. (2011). Faktor Pendukung terhadap Itensi Berwirausaha pada Mahasiswa. Semarang: Journal Unnes.

Paulina, I, dan Wardoyo. (2012). Faktor Pendukung Itensi Berwirausaha terhadap Mahasiswa. Fakultas Ekonomi, Universitas Gunadarma. Jakarta: Jurnal Dinamika Manajemen. Vol 03, No 01, Maret 2012.

Pratiwi, Y. dan Wardana, M.I. (2016). Pengaruh Faktor Internal dan Eksternal Terhadap Minat Berwirausaha Mahasiswa Fakultas Ekonomika dan Bisnis Universitas Udayana. Bali: Ejurnal Manajemen Unud. ISSN: 2302- 8912.

Raguz, I. V. dan Matic, M. (2011). Student's Perceptions and Intentions Towards Entrepreneurship: The Empirical Finding from The University of Dubrovnik - Croatia. International Journal of Management Cases, Vol. 13 No. 3, 38-49.

Rosmiati, J, danMunawar. (2015). Sikap, Motivasi, dan Minat Kewirausahaan Mahasiswa. Kupang: online ISSN: 2338-8234

Slamet, M. (2003). Membentuk pola perilaku manusia pembangunan.

Sugiyono, S. (2007). Metode Penelitian Kualitatif Kuantitatif dan R \& D. Bandung Alf.

Winarsih, (2014). Minat berwirausaha ditinjau dari motivasi dan sikap kewirausahaan pada mahasiswa program studi pendidikan akuntansi fakultas keguruan dan ilmu pendidikan UMS angkatan 2011/2012. Surakarta: eprint UMS. 